\title{
DIFFERENTIATED INTEGRATION IN THE EUROPEAN UNION: MANY CONCEPTS, SPARSE THEORY, FEW DATA
}

\author{
Katharina Holzinger and Frank Schimmelfennig
}

\begin{abstract}
Differentiated integration has been the subject of political discussion and academic thought for a long time. It has also become an important feature of European integration since the 1990s. By contrast, it is astonishing how poor our research and knowledge about the phenomenon is. Whereas there is an abundance of conceptual work and some normative analysis, positive theories on the causes or effects of differentiated integration are rare. Empirical analysis has concentrated on a few important cases of treaty law (such as EMU and Schengen) while there is no systematic knowledge about differentiated integration in secondary law. The aim of this article is therefore twofold: to review the existing typological and theory-oriented research and to outline a research agenda striving for systematic empirical and explanatory knowledge.
\end{abstract}

KEY WORDS Differentiated integration; European integration; flexible integration.

\section{INTRODUCTION}

Some rules and policies of the European Union (such as monetary policy) apply to a subset of the member states only; others (such as many internal market rules) have been adopted by non-members; others again (such as the Schengen regime) do not apply in some of the member states but apply in some nonmember states. All of these policies, in which the territorial extension of European Union (EU) membership and EU rule validity are incongruent, are cases of differentiated (or flexible) integration.

Differentiated integration has been the subject of political discussion and academic thought for a long time. Since the 1970s, a great number of concepts and proposals have been put forward by political practitioners as well as legal and political science scholars. The longevity of opt-outs and exclusions from European Monetary Union (EMU) and Schengen, the selective integration of nonmembers that do not want to join or are not allowed to join (as in the European Economic Area, the Bilateral Agreements with Switzerland, or the Customs Union with Turkey), or the establishment and increased use of the Enhanced 
Co-operation procedure demonstrate that differentiated integration has also become an important and - most probably - permanent feature of European integration.

Given the relevance of differentiated integration in the debate about and reality of European integration, it is astonishing how poor or patchy and imbalanced our research and knowledge is. Whereas there is an abundance of conceptual work and some normative analysis (mainly by lawyers and economists), theories on the causes or effects of differentiated integration are extremely rare. Empirical analysis has been limited to a few important cases of treaty law (such as EMU and Schengen), but there are no comprehensive data sets. In addition, there is no systematic knowledge at all about differentiated integration in secondary law.

The aim of this article is twofold: to review the existing typological and theory-oriented research and to outline a research agenda. We cannot include atheoretical work or descriptive case studies for reasons of space. In the first part of the article, we review the concepts and models and classify them according to a number of criteria (Section 2). Second, we give an account of the positive theories of differentiated integration (Section 3). Section 4 concludes with a research agenda.

\section{NORMATIVE CONCEPTS}

There is a long history of normative concepts and policy prescriptions for flexible integration in the EU. Models of differentiated integration are usually discussed against the background of total harmonization throughout the entire EU. The politicians and academics proposing these models, however, argue from different perspectives. Policy-makers and political scientists usually start from the assumption that flexible models allow for further integration that would otherwise be blocked by the lack of political will in some member states or by increasing heterogeneity among the members. By contrast, economists view total harmonization as inefficient. They suggest tailoring the scope of EU rules to the area affected by transnational externalities.

\subsection{Political concepts of differentiated integration}

Political scientists and policy-makers have focused on proposing designs of differentiation for the EU as a whole. The idea of flexible integration appears already in the thoughts of Jean Monnet (Stubb 1996). The discussion of different models of differentiated integration started with the Tindemans Report of 1976 (cf. Stubb 1996). The debate became lively during the 1990s. In view of the imminent Eastern enlargement, ever more proposals for various forms of differentiated integration were tabled, leading to a confusing abundance of concepts. Stubb (1996) lists about 30 models. In the following we briefly outline the most discussed ones, ordered along the criterion of how far each model deviates from the current legal conception of the EU. 
The concept of a 'Two- or Multiple-speed Europe' is closest to the current EU. Differentiation is purely temporal, it relates only to member states (and not to non-members or sub-national units) and it is implemented inside the European treaties. The concept aims at the introduction of a federal political union in several steps, whereby some states co-operate closer at an earlier point in time while others follow suit later (Grabitz 1984).

'Avantgarde Europe' envisions a union that is formed by member states of which some represent the 'avant-garde' (Club von Florenz 1996). Each state has fixed membership in either one of the two groups. Similarly, the models of 'Core Europe', and 'Europe of Concentric Circles (Schäuble and Lamers 1994) conceptualize a core of a federal political union formed by some member states, whereas other member states constitute a second circle; however, non-member states willing to join some policies are allowed to form a third circle. Only members of the core take decisions concerning the political union.

By contrast, the concepts of 'Flexible Integration' (Centre for Economic Policy Research 1995), 'Variable Geometry' and 'Differentiated Integration' (Bertelsmann Forum International 1997) aim at functional regimes with sector-specific differentiation. 'Flexible Integration' includes only member states. Decisions within the regimes are taken either using the supranational procedures or intergovernmental negotiation. The establishment of functional regimes is only possible outside the treaties. Variable Geometry and Differentiated Integration are open to both member and non-member states. Decisions are taken by all EU members (plus non-EU regime members); non-participating EU members should abstain from voting. The regimes shall be established on the basis of the EU treaties. By contrast, 'external governance' focuses exclusively on non-member states (see Schimmelfennig and Wagner 2004; Lavenex and Schimmelfennig 2009). Similar in this respect to Variable Geometry, external governance is characterized by the sector-specific extension of the EU's acquis to non-member states.

'Europe à la carte' is rather distant to the EU as it exists. Again, the aim is the creation of sector-specific functional regimes which are, however, fully based on intergovernmental decision-making. Each country can join each regime in which it is interested and only regime members take part in decision-making. This way no fixed full membership in the EU exists anymore. The regimes are formed outside the treaties (Dahrendorf 1979).

Most of these concepts retain the basic structure of the EU. They do not touch the principle of territoriality and the multi-level system. The upper level consists of the EU or functional regimes, the lower level of nation states. What they give up is the pyramid-like structure that fully integrates the lower-level jurisdictions into the next higher level. None of these concepts affects the sub-national level.

Fritz Scharpf (1999: 151ff.) went somewhat further, proposing the permanent co-existence of multiple standards as an explicit principle for the EU. He proposed to introduce different standards for different groups of members 
on a permanent basis, the strictness of them depending on the countries' willingness. Scharpf's model addresses a problem that has not usually been in the minds of political scientists developing concepts for differentiated integration: the incongruence of the spatial scope of political problems and of nation states.

\subsection{Economic models: fiscal and functional federalism}

The economic theory of fiscal federalism deals explicitly with the potential incongruence of the spatial scope of problems and political territories, which may lead to spatial externalities. As a consequence, decisions within a single jurisdiction are inefficient. Mancur Olson (1969) proposed a normative solution, the principle of fiscal equivalence, which formulates the conditions under which a public good is efficiently produced by a jurisdiction. Efficient solutions are achieved whenever the users of the good, the taxpayers and the decisionmakers are identical. If the spatial reach of a public good is determined by physical conditions (such as in environmental problems), the jurisdictions have to be adapted to the reach of the problem. If, however, the citizens of certain regions have different preferences with respect to a given public good or a policy, then the citizens of these regions should take their own decision.

Based on the principle of fiscal equivalence, legislative competencies should be allocated to the adequate levels of jurisdiction. Local problems ought to be solved at the communal level, nation-wide problems at the nation states level, transboundary or global problem at the EU or United Nations (UN) level. Fischer and Schley (1999) provide a scheme for EU competence allocation along those lines. Such a static allocation of competencies is, however, only an incomplete solution. A concept for more flexible co-operation across several levels of jurisdictions would be needed to overcome the inefficiencies caused by spatial externalities. Yet the Olsonian approach does not give up the principle of territoriality.

Much more radical, functional federalism suspends territoriality and proposes the creation of jurisdictions that are purely functional and independent of space and political borders. The most prominent example of functional federalism is the concept of Functional Overlapping Competing Jurisdictions (FOCJ) of Frey and Eichenberger (1996; cf. Frey 1996, 1997). FOCJ are jurisdictions insofar as they possess the right to tax and the right to take and implement collectively binding decisions. FOCJ are created on a functional basis; they are defined by a certain task. The adaptation to spatial externalities and political preferences happens therefore endogenously and in a flexible manner. FOCJ can be geographically overlapping; that is, we do not see a pyramid-like structure as in classical federalism. Spatial overlapping is possible in two dimensions. First, FOCJ that fulfil different tasks may cover the same geographical spaces. Second, it is also possible that FOCJ with the same function cover geographical overlap. They might offer the same public good (e.g., schooling or social security) at different levels of quality and price. This implies that the FOCJ compete with each other as in a market. The individual members can choose to which 
FOCJ they want to belong. Exit and entry are free. Moreover, the performance of a FOCJ is tied to the preferences of its members in a second way because the members take direct-democratic decisions (Frey 1996: 318).

Two aspects of the FOCJ concept are noteworthy. First, the functionality of FOCJ allows for the flexible adaptation of jurisdictions to the scope of the regulatory problem. Second, however, the competition of FOCJ with the same function will not be practicable in many cases. Since we are talking of public goods provision, the competition principle will usually not allow for achieving desirable political results, but it might lead to races to the bottom in provision or regulatory level.

Holzinger (2000) therefore develops a concept for flexible co-operation in the $\mathrm{EU}$ that is based on the principle of equivalence and permits a flexible design of institutions, without sacrificing a high level of public goods provision to regulatory competition. Holzinger's concept proposes the functional co-operation of existing territorial jurisdictions. It is a multi-level model; that is, the co-operation may include not only member states but also sub-national jurisdictions from EU member states, and even non-member states. It can be implemented within the European treaties. Decisions are taken by the members of a flexible co-operation, not by all EU member states. The concept implies the sacrificing of the idea of unitary states and a unitary EU and might gradually dissolve inner-European borders.

\subsection{Classifications of differentiated integration}

Can we bring some conceptual order to the great variety of prescriptive and descriptive concepts of differentiated integration? Alexander Stubb's threeway classification (1996) has become widely accepted and used. He distinguishes concepts based on:

- temporal differentiation ('time'), such as Two- or Multi-speed Europe;

- territorial differentiation ('space'), such as Core Europe or Europe of Concentric Circles; and

- sectoral differentiation ('matter'), such as Variable Geometry or Europe à la carte.

The problem of this classification is that its dimensions are not analytically distinct. Whereas the distinction between temporary and permanent differentiation holds, space and matter are by definition involved in all types of differentiation. Differentiation always has a territorial aspect, as some countries or regions do not participate in integration; and it always has a sectoral aspect, because it applies to specific policies or rules. The difference between Stubb's second and third group is not one between space and matter but between fixed and flexible membership in regimes. Moreover, Stubb's list does not include the purely functional conceptions.

The concepts described above vary with respect to more than Stubb's three categories. We suggest that they be distinguished along six dimensions: 
(1) permanent $v$. temporary differentiation;

(2) territorial v. purely functional differentiation;

(3) differentiation across nation states v. multi-level differentiation;

(4) differentiation takes place within the EU treaties v. outside the EU treaties;

(5) decision-making at EU level v. at regime level;

(6) only for member states $\mathrm{v}$. also for non-member states/areas outside the EU territory.

The 10 models presented above have a value at each dimension. Each concept is distinct from all others with respect to at least one criterion, while they share other criteria. Obviously, the 10 concepts do not cover all logically possible combinations. The classification is empirically complete, however - insofar as this review covers all substantively different proposals. Table 1 gives an overview of the concepts, the dimensions, some examples and the associated literature.

Although most of the models have a normative or prescriptive character, we can find empirical examples in the existing EU for all of them - with the exception of FOCJ (see Tuytschaever 1999). This suggests that differentiated integration comes in an astonishing variety of forms and that the concepts of differentiated integration can and should be used systematically to describe these forms and their frequency.

\section{ISLANDS OF THEORIZING}

Positive theoretical approaches to the study of differentiated integration have been limited. On the one hand, theorizing about differentiated integration suffers from the neglect of 'grand' integration theories. On the other hand, case studies and prescriptive, policy-oriented work often indulge in ad hocery. In between, we find a few islands of systematic theory dealing with specific aspects of differentiated integration.

Integration theories have traditionally focused on explaining vertical integration, i.e., the formal transfer of competencies from the national to the European level. While early integration theory may be excused because differentiation was negligible in the 1960s and 1970s, the renewed debate of the 1990s between (liberal) intergovernmentalism and supranationalism took place at a time when differentiation had become politically salient and an important feature of European integration (Kölliker 2006: 38). Even though Moravcsik and Nicolaidis (1999: 83) describe instances of differentiation in the bargaining processes of the Amsterdam treaty negotiations and call for elaborating bargaining theory to deal adequately with exclusion and opt-outs, differentiated integration has not been treated systematically in liberal intergovernmentalism - let alone in supranationalist theories, with their focus on centralization and institutionalization in European integration.

By contrast, we find numerous studies and treatises on differentiated integration that focus on describing the phenomenon or evaluating its desirability but do not provide any explicit theory. There is, nevertheless, some kind of 
Table 1 Overview of models of differentiated integration

\begin{tabular}{|c|c|c|c|c|c|c|c|c|c|c|}
\hline Dimension & & & & & & & & & & \\
\hline 1 & Temporary & \multicolumn{9}{|c|}{ Permanent } \\
\hline 2 & \multicolumn{9}{|c|}{ Territorial } & Functional \\
\hline 3 & \multicolumn{7}{|c|}{ Differentiation at nation-state level } & \multicolumn{3}{|c|}{ Multi-level differentiation } \\
\hline 4 & \multicolumn{4}{|c|}{ Only inside EU treaties } & \multicolumn{3}{|c|}{ Also outside EU treaties } & Only inside & \multicolumn{2}{|c|}{ Also outside EU treaties } \\
\hline 5 & \multicolumn{6}{|c|}{ EU decision-making } & \multicolumn{4}{|c|}{ Club decision-making (intergovernmental) } \\
\hline 6 & \multicolumn{3}{|c|}{ Only member states } & $\begin{array}{l}\text { Also non- } \\
\text { members }\end{array}$ & Only members & \multicolumn{2}{|c|}{ Also non-member states } & Only members & \multicolumn{2}{|c|}{ Also jurisdictions outside EU } \\
\hline & 1 & 2 & 3 & 4 & 5 & 6 & 7 & 8 & 9 & 10 \\
\hline Models & $\begin{array}{l}\text { Multiple } \\
\text { Speed }\end{array}$ & $\begin{array}{c}\text { Multiple } \\
\text { Standards }\end{array}$ & $\begin{array}{l}\text { Avantgarde } \\
\text { Europe }\end{array}$ & $\begin{array}{l}\text { Core Europe, } \\
\text { Concentric } \\
\text { Circles }\end{array}$ & $\begin{array}{c}\text { Flexible } \\
\text { Integration }\end{array}$ & $\begin{array}{l}\text { Variable } \\
\text { Geometry }\end{array}$ & $\begin{array}{l}\text { Europe à la } \\
\text { carte }\end{array}$ & $\begin{array}{l}\text { Optimal Level } \\
\text { of Jurisdiction }\end{array}$ & $\begin{array}{l}\text { Flexible Co- } \\
\text { operation }\end{array}$ & FOC \\
\hline Examples & $\begin{array}{l}\text { Many in } \\
\text { secondary } \\
\text { law }\end{array}$ & $\begin{array}{c}\text { In secondary } \\
\text { law, e.g. } \\
\text { environmental } \\
\text { policy }\end{array}$ & $\begin{array}{c}\text { EMU, } \\
\text { basic rights } \\
\text { charta }\end{array}$ & $\begin{array}{c}\text { EMU; } \\
\text { EEA, } \\
\text { associated } \\
\text { states }\end{array}$ & $\begin{array}{l}\text { Enhanced Co- } \\
\text { operation, } \\
\text { Bologna } \\
\text { (at the start) }\end{array}$ & Schengen & Bologna & $\begin{array}{l}\text { Competence } \\
\text { allocation in } \\
\text { Lisbon Treaty }\end{array}$ & EUREGIOS & No example \\
\hline References & $\begin{array}{c}\text { Grabitz } \\
(1984) \\
\text { Stubb } \\
(1996,2002)\end{array}$ & $\begin{array}{l}\text { Scharpf } \\
\text { (1999) }\end{array}$ & $\begin{array}{l}\text { Club von } \\
\text { Florenz } \\
\text { (1996) }\end{array}$ & $\begin{array}{c}\text { Schäuble and } \\
\text { Lamers } \\
\text { (1994) }\end{array}$ & $\begin{array}{c}\text { Centre for } \\
\text { Economic } \\
\text { Policy } \\
\text { Research } \\
\text { (1995) } \\
\end{array}$ & $\begin{array}{l}\text { Stubb } \\
\text { (1996) }\end{array}$ & $\begin{array}{l}\text { Dahrendorf } \\
\text { (1979) }\end{array}$ & $\begin{array}{l}\text { Fischer and } \\
\text { Schley } \\
\text { (1999) }\end{array}$ & $\begin{array}{l}\text { Holzinger } \\
(2001)\end{array}$ & $\begin{array}{l}\text { Frey and } \\
\text { Eichenberger } \\
(1996,1997)\end{array}$ \\
\hline
\end{tabular}


'folk theorem', a widespread conventional wisdom about the general causes of differentiation. The conventional story attributes differentiation to an increase in heterogeneity among the member states triggered mainly by enlargement rounds but also by broadening the functional scope of EU-level policymaking and the centralization or supranationalization of decision-making. This heterogeneity concerns member state preferences ('will') as well as their capabilities. Increased heterogeneity, in turn, threatens to create deadlock in an organization based to a large extent on intergovernmental consensus most clearly so in the case of treaty negotiations and amendments but, given the high qualified majority requirements of legislative decision-making, also in secondary legislation. Differentiated integration helps to overcome deadlock by allowing the member states (and non-member states) to co-operate at different levels of integration (e.g., Dyson and Sepos 2010: 5-6, 14-15; Holzinger 2011; Majone 2009: 221; Stubb 1997; Warleigh 2002).

This basic story has strong initial plausibility but is indeterminate. First, we would want to know more precisely what kind of heterogeneity matters (most). Heterogeneous preferences could be material or ideational, societal or governmental. Second, the conventional story is highly demand-driven and neglects the supply side of integration. Differentiated integration does not result spontaneously from preference heterogeneity but creates second-order problems such as transaction costs and externalities, and it may produce institutional resistance. Finally, the differentiation outcome is indeterminate. It would be equally plausible to predict that increased heterogeneity results in stagnation or the decline of integration. There are, however, a few islands of theorizing that go beyond this basic story. We will group them roughly into rationalist and normative/institutionalist approaches.

\subsection{Rationalist approaches}

In most rationalist approaches to explaining differentiated integration, collective goods and the externalities they create play a central role. An early example is Thomas Gehring's (1998) analysis of the Schengen regime. In line with the conventional wisdom, he explains Schengen as the establishment of a regime outside the treaty framework to overcome a deadlocked situation. Once established, however, Schengen changed the incentive structure for the outsiders. First, it created a focal point limiting the options of the outsider states to either accepting Schengen or rejecting passport-free travel altogether. Second, the stricter external border controls created costs for the outsiders. And third, because Schengen was excludable, it deprived the outsiders of free-riding opportunities. For those outsiders whose preferences were not too far off from the Schengen rules, the regime thus created an incentive to join.

Alkuin Kölliker $(2001,2006)$ builds a general account of the relationship between properties of collective goods and differentiated integration on Gehring's pilot study. Whereas excludable goods generate strong incentives for the initially unwilling' to join, non-excludable goods allow the outsiders to free-ride. Rivalry 
in consumption is a secondary influence, which reduces the outsiders' incentives to join. Thus, excludable goods with complementary consumption (excludable network goods) create the strongest, and non-excludable goods with rival consumption (common pool resources) create the weakest, centripetal effects. On this basis, Kölliker (2006: 103-4) formulates two linked hypotheses: both (a) the willingness of integrationist member states to establish differentiated integration arrangements; and (b) the willingness of initially opposed members to join these arrangements later, increases with their centripetal effects (i.e., mainly with excludability; see also Harstad [2006]). Kölliker corroborates these hypotheses in a comparative study of 15 cases in five policy areas from the mid1980 s to the end of the 1990s.

Kölliker's book is the theoretically and empirically most comprehensive study of differentiated integration to date. Its rational-intergovernmentalist assumptions provide for a simple and elegant analysis but also cause some limitations. It does not allow for decision-making rules other than unanimity, for 'ideological' preferences that may override the goods-based incentives, or for domestic constraints forcing governments to opt out (Kölliker 2006: 106-7). These factors may explain the empirical cases that contradict his expectations. That EMU as an excludable network good has failed to create centripetal effects on the opt-out countries can be attributed to (anticipated) negative referendums, and the United Kingdom's eventual participation in the Maastricht Social Protocol resulted from an ideological shift in the government rather than centripetal policy effects.

Jensen and Slapin (2011) go beyond Kölliker by including member state preferences, agenda-setting and qualified majority voting in a spatial model of decision-making on differentiated integration. It is an interesting implication of their model that differentiation alters the identity and location of the pivotal actor and thus moves the policy outcome in an integrationist direction, which may make it even harder for outsiders to join later. This centrifugal effect differs from non-excludability.

Christina Schneider (2009; see also Plümper and Schneider 2007) examines a special case of differentiated integration: the transitional qualification of membership rights for new member states. In line with the conventional story, 'discriminatory membership' is used as an instrument to overcome deadlock - here, deadlock in accession negotiations deriving from conflict about the distribution of gains and losses from the accession of new member states. To the extent that the candidate states are in a weak bargaining position, i.e., have no credible alternatives to accession while old member states can afford to reject them, member states can credibly threaten to veto enlargement unless the candidates are excluded from those rights and entitlements that produce net losses for the old members. In an analysis of all EU enlargement rounds and major policies with redistributive implications (agriculture, structural funds, free movement of labour), Schneider shows that both member state demands for, and eventual agreements on, transitional arrangements are driven by distributional conflict. 
In the dissemination of $\mathrm{EU}$ rules beyond the candidate and new member states, bargaining power is also regarded as crucial (Lavenex and Schimmelfennig 2009: 803). This bargaining power is policy-specific: the higher and the more asymmetrical (in favour of the $\mathrm{EU}$ ) the policy-specific interdependence with the EU, the more likely a non-member state will accept and adopt EU rules as the basis of co-operation. Even though this hypothesis has not yet been tested as systematically as discriminatory membership, many case studies and comparative analyses corroborate the correlation between EU bargaining power and rule export (see, for example, Barbé et al. [2009] on foreign and security policy; Dimitrova and Dragneva [2009] on EU-Ukraine relations; Lavenex and Stuhlberg [2007] on energy policy).

\subsection{Ideational and institutional factors}

The distribution of preferences, bargaining power, formal voting rules and the externalities of differentiation have been established as core ingredients to a theory of differentiated integration. Yet the rationalist accounts reviewed above also generally refer to normative and institutional factors, which are, however, not fully integrated into the theoretical models. Gehring (1998) refers to the higher legitimacy of the Community framework as a reason for reinserting the Schengen regime into the EU, and Schneider (2009: 69) accepts that the norm of legal unity constrains the duration of discriminatory arrangements for new member states. Kölliker (2006: 106-7) concedes that ideological factors at the level of parties and mass identities may confound the intergovernmental and functional logic of collective goods, and Jensen and Slapin (2011: 6) combine a variety of reputational and ideational costs under the heading 'non-policy costs'. These factors need to be better specified theoretically and properly integrated into an explanatory framework.

In a series of articles, Rebecca Adler-Nissen $(2008,2009,2011)$ draws our attention to how informal institutional practice mitigates the formal institutional divides created by differentiation. She argues that national role conceptions and informal norms shape the interactions between the core and the opt-out countries. She finds in particular that the 'consensus norm' emphasized in constructivist research prevents Danish and British officials from being left out in the cold and that both countries have influence and adopt EU legislation even in areas that are covered by their opt-outs. In the same vein, Naurin and Lindahl (2010) show that the Euro-outsiders Denmark, the United Kingdom (UK) and Sweden do not suffer from a bad reputation and possess high network capital, and Dyson and Marcussen (2010) describe the 'fuzzy' governance structures that transcend the formal boundary between eurozone and opt-out countries.

These studies point to important aspects of differentiated integration neglected or poorly specified by rationalist approaches: the value- or identitydriven demand behind differentiated integration; the legitimacy constraints on differentiated integration; and institutional features of the EU such informal 
institutionalization, informal norms of decision-making and socialization effects that mitigate and supersede differentiation.

\section{CONCLUSIONS: THE AGENDA}

The literature on differentiated integration shows a striking imbalance between overconceptualization, undertheorization and even less systematic data collection and analysis. A mushrooming of categories and classifications goes hand-in-hand with few islands of positive theory. The purpose of this article has been to describe this situation and to give a systematic overview of where . we stand in theorizing differentiated integration. On this basis, we draw some general conclusions on where research on differentiated integration should go in the future.

The first section of this article has reviewed the great variety of concepts and typologies of differentiated integration in legal, political and economic scholarship. As a first step towards conceptual consolidation, we have made a proposal for an integrated typology. It is furthermore interesting to see that for most of these concepts we actually find empirical examples. Yet there are three challenges ahead. For one, the typology needs to prove its theoretical worth. Can we formulate theoretically meaningful hypotheses about the causes and effects of differentiated integration based on the conceptual distinctions? In addition, valid and reliable indicators for measuring different types of differentiated integration are required. Finally, we do not have the data that would allow us saying anything about the frequency and development of the types of differentiation or their distribution across policies, countries or types of regulation.

This leads us to the second item on the research agenda: systematic data collection. So far, studies of differentiated integration have almost exclusively focused on a few prominent cases of treaty-based differentiation, EMU and Schengen in particular. Whereas these cases are politically relevant and heuristically useful, it is not clear how paradigmatic or representative they are. Moreover, research has mostly started from positive cases of differentiated integration, whereas we know little about the 'dogs that didn't bark', i.e., integration outcomes under similar conditions as Schengen or EMU, which should have led to differentiation but did not. Most importantly, we know close to nothing about differentiated integration in ordinary Community legislation and the EU's secondary law. Given that the actors and decision-making procedures are different from those in intergovernmental negotiations and domestic ratifications, the patterns could distinguish themselves from those in treaty law. Finally, we would like to know and explain how differentiated integration has developed over time and how primary-law and secondary-law differentiation have interacted. These knowledge gaps call for the systematic collection of both longitudinal and cross-sectional data on differentiated integration.

In addition, the islands of theorizing need to be enlarged and better linked. Mainstream integration needs to pay more attention to differentiation as an integration outcome. The nature and origin of preferences for or against 
differentiation have been treated as exogenous in existing approaches and need to be explained and endogenized. Ideational and institutional factors need to be better integrated into the well-elaborated decision-making models that we already have for differentiated integration. Finally, existing approaches focus on specific stages (pre- and post-differentiation) and contexts of differentiation (deepening, enlargement, external governance). Are these different types of differentiation requiring different explanations, or can we find a unified theoretical framework for them?

Regarding the effects of differentiated integration, the focus has so far been on theorizing the consequences for future integration in the same area (Kölliker 2006; Jensen and Slapin 2011). In addition, however, research should also address the immediate policy effects of differentiation: does it facilitate policymaking, problem-solving and implementation, or does it confirm concerns about legal uncertainty, free-riding or venue-shopping? And while the observable time span may still be too short, it would also be interesting to learn more about the effects of differentiated integration on the $\mathrm{EU}$ as a whole: does it put the EU on a slippery slope toward a permanent core-periphery structure or dissolution, or does it create a fresh impetus for further deepening?

Finally, differentiated integration should not be studied in isolation from other methods of dealing with heterogeneity and conflict in the EU. In some cases, member states may choose non-compliance over negotiating differentiation in order to avoid costly policy obligations (see Andersen and Sitter [2006] for a proposal to study legal differentiation and practical compliance in conjunction). Moreover, soft rules that are uniformly valid in all member states but, for instance, less binding, give countries more times to adapt, or only specify minimum harmonization requirements are another way of accommodating diversity by introducing flexibility.

Biographical notes: Katharina Holzinger is a Professor at the University of Konstanz, Germany. Frank Schimmelfennig is a Professor at the Centre for Comparative and International studies, Zurich, Switzerland.

Addresses for correspondence: Prof. Dr Katharina Holzinger, Department of Politics and Public Administration, University of Konstanz, Box 90, D-78457 Konstanz. email: Katharina.holzinger@uni-konstanz.de/Prof. Dr Frank Schimmelfennig, ETH Zurich, Center for Comparative and International Studies, IFW D 45.1, CH-8092 Zürich. email: Schimmelfennig@eup.gess.ethz.ch

\section{REFERENCES}

Adler-Nissen, R. (2008) 'The diplomacy of opting out: a bourdieudian approach to national integration strategies', Journal of Common Market Studies 46(3): 663-84.

Adler-Nissen, R. (2009) 'Behind the scenes of differentiated integration. Circumventing national opt-outs in justice and home affairs', Journal of European Public Policy 16(1): 62-80. 
Adler-Nissen, R. (2011) 'Opting out of an ever closer Union: the integration doxa and the management of sovereignty', West European Politics 34(5): 1092-113.

Andersen, S. and Sitter, N. (2006) 'Differentiated integration', Arena Working Paper 05, Oslo.

Barbé, E., Costa, O., Herranz, A. and Natorski, M. (2009) 'Which rules shape EU's external governance? The pattern of rule selection in foreign and security policies', Journal of European Public Policy 16(6): 834-52.

Bertelsmann Forum International (1997) Das neue Europa. Strategien differenzierter Integration, Gütersloh: Bertelsmann Stiftung.

Centre for Economic Policy Research (ed.) (1995) Flexible Integration. Towards a More Effective and Democratic Europe, London: Centre for Economic Policy Research.

Club von Florenz (ed.) (1996) Europa: Der unmögliche Status quo, Baden-Baden: Nomos.

Dahrendorf, R. (1979) 'A Third Europe? Third Jean Monnet Lecture, Florenz, 26 November.

Dimitrova, A. and Dragneva, R. (2009) 'Constraining external governance: interdependence with Russia and the CIS as limits to EU's rule transfer in Ukraine', Journal of European Public Policy 16(6): 853-72.

Dyson, K. and Marcussen, M. (2010) 'Transverse integration in European economic governance: between unitary and differentiated integration', Journal of European Integration 32(1): 17-39.

Dyson, K. and Sepos, A. (2010) 'The political dimension: differentiation as design principle and as a tool of political management in European integration', in K. Dyson and A. Sepos (eds), Which Europe? The Politics of Differentiated Integration, Basingstoke: Palgrave Macmillan, pp. 3-23.

Fischer, T. and Schley, N. (1999) Europa foderal organisieren. Ein neues Kompetenz- und Vertragsgefüge für die Europäischen Union, Bonn: Europa-Union.

Frey, B. (1996) 'A directly democratic and federal Europe', Constitutional Political Economy 7: 267-79.

Frey, B. (1997) Ein neuer Föderalismus für Europa: Die Idee der FOCJ, Tübingen: Mohr Siebeck.

Frey, B. and Eichenberger, R. (1996) 'FOCJ. Competitive governments for Europe', International Review of Law and Economics 16(3): 315-27.

Gehring, T. (1998) 'Die Politik des koordinierten Alleingangs. Schengen und die Abschaffung der Personenkontrollen an den Binnengrenzen der Europäischen Union', Zeitschrift für Internationale Beziehungen 5(1): 43-78.

Grabitz, E. (ed.) (1984) Abgestufte Integration. Eine Alternative zum herkömmlichen Integrationskonzept, Kehl: Engel.

Harstad, B. (2006) 'Flexible integration? Mandatory and minimum participation rules', Scandinavian Journal of Economics 108(4): 683-702.

Holzinger, K. (2000) 'Optimal regulatory units: a concept of regional differentiation of environmental standards in the European Union', in K. Holzinger and P. Knoepfel (eds), Environmental Policy in a Europe of Variable Geometry. The Challenge of the Next Enlargement, Basel: Helbig und Lichtenhahn, pp. 65-107.

Holzinger, K. (2011) 'EU environmental policy in the joint-decision trap? The critical balance between negative and positive integration', in G. Falkner (ed.), Exits from the Joint-Decision Trap: Comparing EU Policies, Oxford: Oxford University Press, pp. 110-27.

Jensen, C. and Slapin, J. (2011) 'Institutional hokey-pokey: the politics of multispeed integration in the European Union', Journal of European Public Policy, http://dx.doi. org/10.1080/13501763.2011.610694.

Kölliker, A. (2001) 'Bringing together or driving apart the Union? Towards a theory of differentiated integration', West European Politics 24(4): 125-51. 
Kölliker, A. (2006) Flexibility and European Unification: The Logic of Differentiated Integration, Lanham, MD: Rowman and Littlefield.

Lavenex, S. and Schimmelfennig, F. (2009) 'EU rules beyond EU borders: theorizing external governance in European politics', Journal of European Public Policy 16(6): 791-812.

Lavenex, S. and Stulberg, A.N. (2007) 'Connecting the neighbourhood: energy and environment', in K. Weber, M.E. Smith and M. Baun (eds), Managing Interdependence in the Wider Europe, Manchester: Manchester University Press, pp. 134-55.

Majone, G. (2009) Europe as the Would-be World Power. The EU at Fifty, Cambridge: Cambridge University Press.

Moravcsik, A. and Nicolaïdis, K. (1999) 'Explaining the Treaty of Amsterdam: interests, influence, institutions', Journal of Common Market Studies 37(1): 59-85.

Naurin, D. and Lindahl, R. (2010) 'Out in the old? Flexible integration and the political status of Euro opt-outs', European Union Politics 11(4): 485-509.

Olson, M. (1969) 'The principle of "fiscal equivalence". The division of responsibilities among different levels of government', American Economic Review 59(2): 479-87.

Plümper, T. and Schneider, C. (2007) 'Discriminatory membership and the redistribution of enlargement gains', Journal of Conflict Resolution 51(4): 568-87.

Schäuble, W. and Lamers, K. (1994) 'Überlegungen zur europäischen Politik. Vorschläge für eine Reform der Europäischen Union, Bonn, 01.09.1994', $C D U$ Dokumentation 1/1995.

Scharpf, F.W. (1999) Regieren in Europa. Effektiv und demokratisch?, Frankfurt and New York: Campus.

Schimmelfennig, F. and Wagner, W. (eds) (2004) 'External governance in the European Union', Journal of European Public Policy 11(4).

Schneider, C. (2009) Conflict, Negotiation and European Union Enlargement, Cambridge: Cambridge University Press.

Stubb, A.C. (1996) 'A categorization of differentiated integration', Journal of Common Market Studies 34(2): 283-95.

Stubb, A.C. (1997) 'The 1996 Intergovernmental Conference and the management of flexible integration', Journal of European Public Policy 4(1): 37-55.

Stubb, A.C. (2002) Negotiating Flexibility in the European Union. Amsterdam, Nice and Beyond, Basingstoke: Palgrave.

Tindemans, L. (1976) 'European Union: report to the European Council. Bulletin of the European Communities', Supplement 1/1976, Luxembourg.

Tuytschaever, F. (1999) Differentiation in European Law, Oxford: Hart.

Warleigh, A. (2002) Flexible Integration. Which Model for the European Union?, Sheffield: Sheffield Academic Press. 